\title{
Bases genéticas de la herencia para características morfológicas, agronómicas y agro industriales en tomate hibrido Solanum lycopersicum L. (Mill.) \\ Genetic basis of inheritance for morphological, agronomic and agro-industries characteristics in hybrid tomato Solanum lycopersicum L. (Mill)
}

\author{
Gabriel Julio ${ }^{1 *}$, López Edy ${ }^{2}$, Magne Jury ${ }^{1}$, Angulo Ada ${ }^{1}$, Luján Rubén ${ }^{1}$, La Torre Jaime ${ }^{2}$, Crespo Mario ${ }^{1}$
}

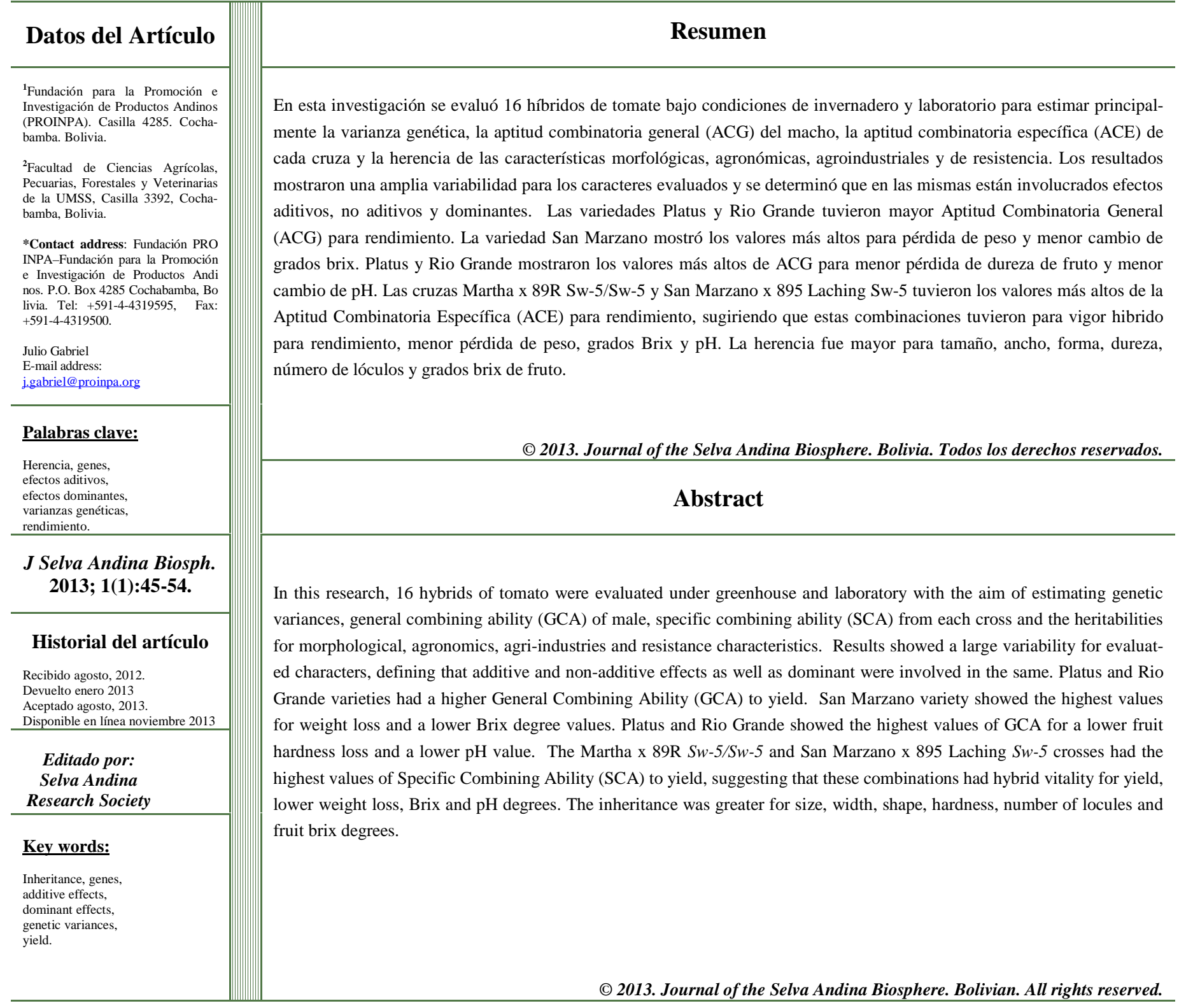




\section{Introduction}

In Bolivia, 6000 ha are cultivated, about $80 \%$ is produced in the department of Santa Cruz. The average yield is $11 \mathrm{t} \mathrm{ha}^{-1}$, equivalent to 500 boxes of $22 \mathrm{~kg}$ (Ghezan 2000, Reque 2010). Most of the tomatoes production is consumed fresh and the bu siness value amounts to about 21 million (CNPSH 2001). The tomato production cost is estimated bet ween 1500 to $2000 \mathrm{US} \$ / \mathrm{ha}^{-1}$ approximately, depending on production areas.

The above background shows the increasing importance of tomato and the need to achieve new toma to hybrids production and resistance to diseases. In the year 2007, the PROINPA Crop Breeding Program evaluated 74 tomato accessions from different parts of the world (Gabriel et al. 2008) but only eight varieties were selected. The latter varieties were self-fertilized during three agricultural cycles in order to achieve parental lines partially homozygous which were later crossed with two carrier lines of Solanum lycopersicum wild genes with resistance to tospo virus (TSWV), achieving 16 hybrids.

Identification and selection of flexible parental lines are required to be used in any hybridization programme to produce genetically modified and potentially rewarding germplasm by assembling fixable gene effects more or less in a homozygous line. Information pertaining to different types of gene action, relative magnitude of genetic variance, and combining ability estimates are important and vital parameters to mould the genetic makeup of tomato crop (Hannan et al. 2007). This important information could prove an essential strategy to tomato breeders in the screening of better parental combinations for further enhance ment. Exploitation of heterosis is primarily dependent on the screening and selection of available germplasm that could be produced by better combinations of important agronomic characters. The entire genetic variability observed in the analysis for each trait was partitioned into its components, i.e. general combining ability (GCA) and specific combining ability (SCA) as defined by Sprague (1966) and reciprocal effects as sketched by Griffing (1956). They stated that GCA effects were due to additive type of gene action and SCA effects were due to non-additive (dominant or epistatic) gene action. Several studies of combining ability for yield components are available in many species. Some researchers found the predominancy of GCA to be more important than that of SCA (Khan et al. 1991, Yaqoob et al. 1997), while others suggested that SCA was more important (Ortiz 2004, Biswas et al. 2005).

The current study was carried out to analyze some important tomato cultivars/genotypes to ascertain the relative performance regarding combining ability effects for morphological, agricultural, agri industries and resistance characteristics.

\section{Materials and methods}

The research was implemented in the 2010-2011 crop year in PROINPA Foundation facilities located in El Paso in Cochabamba, Bolivia, at $17^{\circ}$ $21^{\prime} 00.98^{\prime \prime}$ South latitude, $66^{\circ} 15^{\prime} 47.58^{\prime \prime}$ West longitude and at an altitude of 2617 meters over sea le vel. The area has an average annual temperature of $18{ }^{\circ} \mathrm{C}$ with $55 \%$ of $\mathrm{RH}$ and an average annual rain fall of $569.9 \mathrm{~mm}$, irregularly distributed between the months of November to March. For hybrid 
transplanting (Table 1), level cover plates of $1 \mathrm{x}$ $28.50 \times 0.15 \mathrm{~m}$. took place. Soil was prepared and $2.5 \mathrm{~kg}$ of Nitrophoska per cover plate was applied. For seedling, plastic trays of $15 \times 20 \mathrm{~cm}$ with holes of $10 \mathrm{~cm}$, previously disinfected with detergent and water ( $50 \mathrm{~mL}$ of $\mathrm{Cl} / 1 \mathrm{~L}$ of water) for 5 to $10 \mathrm{~min}$, were used. Substrate was prepared in a ratio: 1:1:1 of rice hull, soil and fine sand sterilized in autoclave for $35 \mathrm{~min}$ at $90{ }^{\circ} \mathrm{C}$. The tray holes were filled by compacting earth in order to prevent air pockets. Seeds were sown in holes of 0.5 to $1 \mathrm{~cm}$ deep and $0.75 \mathrm{~cm}$ diameter. A seed was placed in each hole and covered with disinfested lama, watered immediately at field capacity. The trans plant system consisted in three rolls, in holes of $0.15 \mathrm{~m}$. depth, at a distance of $0.46 \mathrm{~m}$ between holes and within the same row and at a distance of $0.60 \mathrm{~m}$ between rows or furrows. Weeds, pests and diseases were controlled.

According to growth habit, pruning was carried out. In plants of determinate growth habit, three main twigs were pruned and, in plants of indeterminate growth habit in two main twigs. In both cases, the remaining twigs were removed. The staking was performed after pruning. In determinate hybrids, three stakes were placed and two in the in determinate ones. The experiment was implemented under the North Carolina II genetic design in randomized complete blocks with four replications. The 16 hybrids were treated. The experimental unit consisted of 10 plants per hybrid and three plants the sampling unit.

The response variables of the morphological, agronomic and resistance characteristics were evaluated in all sampling units as recommended by IPGRI (2008). To evaluate the agribusiness characteristics such as: shelf-life during 16 days (change in weight and fruit hardness) and chemi47 cal composition ( $\mathrm{pH}$ change and Brix), 18 fruits, per hybrid, was collected in phenological state of $1 / 3$ green and $2 / 3$ ripe, both of the same size. It was also implemented two treatments ( 0 and 16 days in shelf) under a completely randomized design. Based on the defined models, analysis of variance were con ducted to test the hypothesis of fixed effects and average comparisons using contrasts of a freedom degree to determine hybrids with the best morphological, agronomic, agroindustries and resistance characteristics.

The analysis of variance was also used to estimate the variance components for random effects. The indicated analyzes were performed by using Proc GLM of SAS (SAS 2004).

The hybrid genetic analyzes were performed under a Carolina del Norte II design, in which each male $p$ parent mated with females $m$ (Martinez-Garza 1988). The analysis of this design allowed us to estimate the genetic variances of the response variables and to determine the general combining ability (GCA) of male and the specific combining ability (SCA) of each crossing. Also heritabilities in narrow $\left(\mathrm{h}^{2}\right)$ and broad $\left(\mathrm{H}^{2}\right)$ sense were estimated.

\section{Results}

The analysis of variance for 12 variables (morphological, agronomic and resistance) showed visible differences $(\operatorname{Pr}<0.01)$ in number of cells $(\mathrm{NC})$, plant height $(\mathrm{pH})$ and tolerance to nematodes root Knot (Nacobbus aberrans) (TNa). Hybrids with the highest number of cells (4 and 5) were those from the crosses: Anasac $x$ 89R Sw-5/Sw-5, Arthalica x 89R Sw-5/Sw-5 and Magnus x 89R $\mathrm{Sw}-5 / \mathrm{Sw}$. 
Table 1 Agronomic and morphological characteristics of tomato parenteral lines uses to archive 16 tomato hybrids. El Paso. Cochabamba, 2011

\begin{tabular}{|c|c|c|c|c|c|c|c|c|}
\hline \multirow[t]{2}{*}{ Treatments } & \multicolumn{4}{|c|}{ Female } & \multicolumn{4}{|c|}{ Male } \\
\hline & Code & Name & Growth & Fruit & Code & Name & Growth & Fruit \\
\hline Cross & & & Habit & Shape & & & Habit & Shape \\
\hline 17 & 76 & Anasac & Determinado & Redondo & 70 & $89 \mathrm{R} S w-5 / S w-5$ & determinado & Redondo \\
\hline 29 & 76 & Anasac & Determinado & Redondo & 71 & 895 Laching $S w-5$ & determinado & Redondo \\
\hline 6 & 40 & Arthalika & Indeterminado & Alargado & 70 & 89R $S w-5 / S w-5$ & determinado & Redondo \\
\hline 22 & 40 & Arthalika & Indeterminado & Alargado & 71 & 895 Laching $S w-5$ & determinado & Redondo \\
\hline 19 & 3 & Magnus & Determinado & Redondo & 70 & $89 \mathrm{R} S w-5 / S w-5$ & determinado & Redondo \\
\hline 21 & 3 & Magnus & Determinado & Redondo & 71 & 895 Laching $S w-5$ & determinado & Redondo \\
\hline 7 & 41 & Martha & Indeterminado & Alargado & 70 & 89R $S w-5 / S w-5$ & determinado & Redondo \\
\hline 23 & 41 & Martha & Indeterminado & Alargado & 71 & 895 Laching $S w-5$ & determinado & Redondo \\
\hline 18 & 2 & Platus & Determinado & Redondo & 70 & $89 \mathrm{R} S w-5 / S w-5$ & determinado & Redondo \\
\hline 30 & 2 & Platus & Determinado & Redondo & 71 & 895 Laching $S w-5$ & determinado & Redondo \\
\hline 1 & 19 & Rio grande & Determinado & Alargado & 70 & 89R $S w-5 / S w-5$ & determinado & Redondo \\
\hline 15 & 20 & Rio grande & Determinado & Alargado & 71 & 895 Laching $S w-5$ & determinado & Redondo \\
\hline 16 & 46 & San marzano & Determinado & Alargado & 70 & $89 \mathrm{R} S w-5 / S w-5$ & determinado & Redondo \\
\hline 27 & 46 & San marzano & Determinado & Alargado & 71 & 895 Laching $S w-5$ & determinado & Redondo \\
\hline 11 & 35 & Shannon & Indeterminado & Redondo & 70 & $89 R S w-5 / S w-5$ & determinado & Redondo \\
\hline 25 & 35 & Shannon & Indeterminado & Redondo & 71 & 895 Laching $S w-5$ & determinado & Redondo \\
\hline
\end{tabular}

Hybrids (in bold) were selected as the most promising.

Moreover, the progenies with higher height were the crosses: Anasac x 895Laching Sw-5, Arthalica x 895Laching Sw-5, Martha x 895Laching Sw-5 and Shannon $x$ 895Laching Sw-5. Besides, the fruit width (FW), fruit size (FS), fruit length (FL), a transversal cut shape (TCS) and yield (Y) were not significantly different, suggesting that hybrids had the same behavior when evaluated for the variables mentioned.

The variance analysis for shelf-life showed notable differences $(\operatorname{Pr}<0.01)$ for the variable change in Brix grades, suggesting that the change in fruit Brix degrees of at least one of the hybrids, was different. This indicated a large variability in the variation of soluble solids in tomato fruits through the time. By the other hand, the variables: change in fruit weight, fruit hardness and $\mathrm{pH}$, did not presented notable differences, suggesting that the 18 hybrids showed no change in any of the three variables through the time. This lack of variability could be attributed to some degree of relatedness by ancestors in common.

The GCA effect (female; male) and SCA (male $\mathrm{x}$ female) was notorious $(\operatorname{Pr}<0.01)$ for TCS, NL and $\mathrm{PH}$, indicating that the inheritance of these characters would be governed by both additive and nonadditive effects. The magnitude of the latter effects would suggest that these three variables would be effective for hybrid selection. On the other hand, for variables FF, FW, CC, Y, and TNa only the differences between GCAs $(\operatorname{Pr}<0.01)$ were visible, indicating that the inheritance of these characters would be governed mainly by additive effects, therefore the selection through generations could be effective to improve these characters in our population.

Finally, for variables FC, FS, FL and TCS, the GCA and SCA effects were not notorious. Therefore, these variables would not be useful for the selection of ancestors. 
The estimate of genetic variance components, heritability and genetic effects (Table 2) for the twelve variables showed that all they had values of additive and dominance variance greater than zero, suggesting that both genetic effects play an important role in the inheritance of these characters. However, taking into account the importance of gene tic effects $(\gamma<1)$, additive effects would be more important with respect to dominants in all evaluated variables. Given the importance of these additive effects, heritabilities, in narrow sense, were high for all variables. Among these: FW, NL, FSh and FS presented the highest heritability suggesting that these characteristics would be highly heritable for population selection, however, these would not be useful for the selection of hybrids because they would not be expressing hybrid strength.

The estimated GCAs for ancestors (Table 3), showed a wide variability in the behavior of ancestors on different response variables. The Martha, Shannon and Arthalica varieties showed the highest GCAs for TG variable, suggesting that these varieties would be a good source of genes for an in determinate growth. However, Magnus, San Marzano, Platus and Rio Grande varieties would be the best sources of genes for a specific growth (higher negative GCA values). For variable FSh, lines 985 Laching Sw-5 and 89R Sw$5 / \mathrm{Sw}-5$ showed the highest GCAs, indicating that these lines are a source of genes for FSh elongated ellipsoid. The Anasac and Shannon varieties obtained the lowest GCAs, being both good gene sources for round fruits. For FC, San Marzano was the best source of genes for the development of reddish fruits. For FS, Arthalica, Rio Grande and $89 \mathrm{RSw}-5 / \mathrm{Sw}-5$ showed the highest values and can be the carriers of genes for large fruits.
Other variables that allowed a better understanding of FS were FL and FW. For FL, Arthalica, Magnus and Rio Grande had the highest values, while for FW, Arthalica, Shannon and Magnus had greater values, suggesting that Arthalica and Magnus could carry genes for both a higher length and fruit width; whereas Rio Grande and Shannon would only be a source of genes for a higher FL of the first one and, a higher FW, the last one. Martha, San Marzano and Platus varieties would be important sources of genes for round fruits in the transverse level. As to NL, the Martha variety would be the carrier of genes for a lower NL (Table 3) and Anasac, Arthalica and Platus varieties for a higher NL. For Y, Platus and Rio Grande are the ones that achieved higher GCAs, indicating that these varieties would be a good source of genes for a higher $\mathrm{Y}$.

Since the PH depends directly of the growing type, the indeterminate varieties Shannon, Martha and Arthalica presented the highest GCAs and the determinate Magnus variety, the lowest GCA.

Finally, as to the TNa, the Anasac, Platus and Shannon showed the minor negative of GCAs suggesting that these genotypes probably are carrying tolerance genes to rosary-nematode.

Martha crosses x 89R Sw-5/Sw-5 and San Marzano x 895 Laching Sw-5, presented the highest SCAs for Y (Table 3), indicating that these combinations reflect a higher hybrid strength for $\mathrm{Y}$; likewise, the same combinations achieved the lower negative values of SCA for TNa, suggesting that their progenies would be more tolerant to rosary-nematode attack than the remaining pro genies evaluated. 
Table 2 Estimate of genetic variance components, heritability, GCA and SCA of 12 evaluated variables in 16 tomato hybrids. El Paso, Cochabamba, 2011

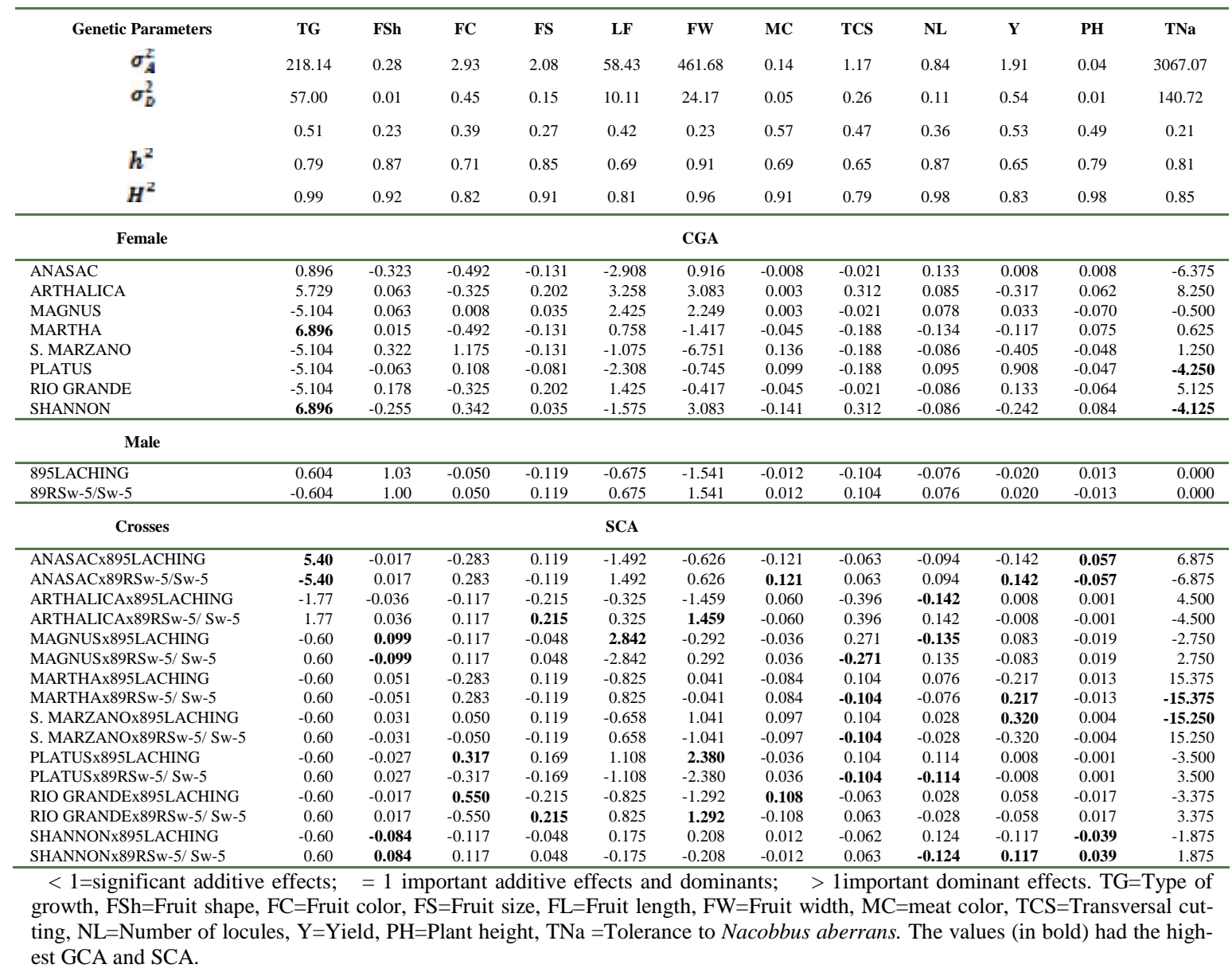

In shelf, the estimate of combining aptitudes showed that differences in males effect (GCA) as well as females (SCA) were significant to $\operatorname{Pr}<0.05$ only for variable change in Brix Grades, suggesting that change in the amount of soluble solids in males and the interaction females $\mathrm{x}$ males was different and evidencing that the inheritance of this character is dominated by genes with additive effects as well as non-additives.

The importance of non-additive effects suggests that this variable would be effective for hybrid selection.
The genetic variance components (Table 3) showed additive and dominance variances with values greater than zero for changing variables in fruit weight and hardness and brix grades, suggesting that changes in fruit weight and hardness and Brix grades would be governed by additive and dominant effects. Instead, the variable change in $\mathrm{pH}$ would only be governed by additive effects. However, considering the importance of genetic effects $(\gamma)$, the additive effects would be more severe for change variables in fruit weight, hardness and $\mathrm{pH}$. On the other hand, in order to change in Brix grades, genes with dominance effects 
would have a higher intensity, confirming that the using this variable.

seletion of hybrids would be more effective by

Table 3 Genetic effects analysis of shelf life for weight, hardness, $\mathrm{pH}$ and Brix in tomato hybrids, El Paso, Cochabamba, 2011

\begin{tabular}{|c|c|c|c|c|}
\hline Variables & Weight (g) & Hardness & Brix grades & pH \\
\hline$\sigma_{A}^{2-}$ & 6.36 & 0.71 & 5.98 & 0.04 \\
\hline$v_{D}^{7}$ & 0.44 & 0.20 & 6.12 & 0.00 \\
\hline$\Gamma$ & 0.26 & 0.53 & 1.01 & 0.00 \\
\hline$F^{2}$ & 0.88 & 0.48 & 0.46 & 0.70 \\
\hline $\boldsymbol{H}^{2}$ & 0.94 & 0.62 & 0.93 & 0.70 \\
\hline Parents & \multicolumn{4}{|c|}{ GCA } \\
\hline \multicolumn{5}{|l|}{ Female } \\
\hline Magnus & -2.62 & 0.21 & 0.55 & 0.04 \\
\hline Marzano & -9.98 & -0.02 & -0.56 & 0.02 \\
\hline Platus & 7.31 & -0.14 & 0.06 & -0.03 \\
\hline Rio grande & 1.23 & -0.13 & 0.03 & -0.03 \\
\hline Shannon & 4.06 & 0.09 & -0.08 & -0.01 \\
\hline \multicolumn{5}{|l|}{ Male } \\
\hline 895 Laching Sw-5 & -2.45 & -0.42 & 0.50 & 0.10 \\
\hline 89R Sw-5/Sw-5 & 15.37 & -0.39 & -0.37 & 0.05 \\
\hline Crosses & \multicolumn{4}{|c|}{ SCA } \\
\hline Magnus x 895 Laching & 0.96 & -0.23 & -0.11 & 0.05 \\
\hline Magnus x 89R Sw-5/Sw-5 & -0.95 & 0.23 & 0.11 & -0.05 \\
\hline Marzano x 895 Laching & 7.93 & -0.09 & 1.42 & 0.03 \\
\hline Marzano x 89R Sw-5/Sw-5 & -7.93 & 0.09 & -1.42 & $-\mathbf{0 . 0 3}$ \\
\hline Platus x 895 Laching & -4.80 & 0.35 & -0.57 & -0.01 \\
\hline Platus x 89R Sw-5/Sw-5 & 4.80 & -0.35 & 0.57 & 0.01 \\
\hline Río grande x 895 Laching & 2.32 & -0.38 & -0.50 & -0.01 \\
\hline Río grande x 89R Sw-5/Sw-5 & -2.32 & 0.38 & 0.50 & 0.01 \\
\hline Shannon x 895 Laching & -6.41 & 0.34 & -0.24 & -0.06 \\
\hline Shannon x 89R Sw-5/Sw-5 & 6.41 & -0.34 & 0.24 & 0.06 \\
\hline
\end{tabular}

The heritability estimate, as from genetic effects (Table 3), showed higher values for both the heritability in narrow $\left(\mathrm{h}^{2}\right)$ and wide $\left(\mathrm{H}^{2}\right)$ sense for changing variables in fruit weight and $\mathrm{pH}$, suggesting that these variables not only have a high genetic variability but also a high heritability from 51 father to son. On the other hand, the change variables in fruit hardness and brix grades presented heritabilities in low narrow sense, suggesting that the selection of tomato hybrids would be more effective through change variables in fruit hard ness and Brix grades. 
The San Marzano variety, presented a lower negative GCA value for changing in fruit weight and brix grades, suggesting that it would be a genes carrier for less weight loss and less change in brix grades while it was subjected to a test of 16-days of shelf-life. On the other hand, the Platus and Rio Grande varieties presented GCAs of lower negative value for change variables in hardness and fruit $\mathrm{pH}$, suggesting that these genotypes would be the carriers of genes for lower hardness loss of fruit and less change of $\mathrm{pH}$ in the fruit pulp during the 16 days (Table 3 ).

For hybrids selection through hybrid strength of new combinations, SCA was estimated for hybrids (Table 3). These estimates showed that crosses San Marzano x 89R Sw5/Sw-5 and Platus x 895Laching had SCAs of lower negative values for change variables in fruit weight and brix grades, suggesting that these combinations had a higher hybrid strength for less weight loss and less change in brix grades for fruits shelf-life. Moreover, the crosses Platus x 89RSw-5/Sw-5 and Rio Grande x 895 Laching Sw-5, showed SCAs of less negative value for changing in fruit hardness, suggesting that these crosses had more hybrid strength for lower hardness loss of fruit during a period of 16 days. Finally, the crosses Shannon x 895 Laching Sw-5 and Magnus x $89 \mathrm{RSw}-5 / \mathrm{Sw}-5$ increased their hybrid strength for less changes of $\mathrm{pH}$, in the course of 16 days.

\section{Discussion}

In our study the GCA effect and SCA was important for TCS, NL and $\mathrm{PH}$, indicating that the inheritance of these characters would be governed by both additive and non-additive effects. The magnitude of the latter effects would suggest that these three variables would be effective for hybrid selection. On the other hand, for variables FF, FW, $\mathrm{CC}, \mathrm{Y}$, and TNa only the differences between GCAs were visible, indicating that the inheritance of these characters would be governed mainly by additive effects, therefore the selection through generations could be effective to improve these characters in our population. Similar reports were also reported by Mirshamsi et al. 2006, Hannan et al. 2007, Sekhar et al. 2010, Govindarasu et al. 1981.

For the variables FC, FS, FL and TCS, the GCA and SCA effects were not important. Therefore, these variables would not be useful for the selection of ancestors.

In our study the yield per plant, showed an important variation due to GCA as well as SCA indicated the importance of additive as well as nonadditive types of gene action in inheritance of this trait. This finding is in close agreement with Mital \& Singh 1977, Prata et al. 2003, Mirshamsi et al. 2006, Ahmad et al. 2009, Sekhar et al. 2010, Akram et al. (2012).

The genetic variance components showed additive and dominance variances with values greater than zero for changing variables in fruit weight and hardness and brix grades, suggesting that changes in fruit weight and hardness and Brix grades would be governed by additive and dominant effects. Instead, the variable change in $\mathrm{pH}$ would only be governed by additive effects. Similar resultants was found by Hannan et al. (2007) en Bangladesh whose evaluated a set of tomato. They reported in this study that the magnitudes of variance due to general as well as specific combining ability for Brix grades were highly significant indicating the importance of both additive and non-additive gene action. 


\section{Conflicts of interest}

This research was realized in the PROINPA Foundation and no conflicts of interest.

\section{Acknowledgements}

We thank the financial support of projects: Fontagro - Development and evaluation of genetic resources of Lycopersicon spp. for use in breeding Solanaceae against biotic and abiotic stresses (ID: 8071) and "Strengthening participatory innovation capabilities to combat rural poverty" (IP - Netherlands).

\section{Cited references}

Ahmad S, Quamruzzaman AKM, Nazim Uddin M. Combining ability estimates of tomato (Solanum lycopersicum) in late summer. SAARC J Agri 2009; 7(1):43-56.

Akram F, Hossein N, Hossein A, Amin Mirshamsi K, Navid V. The Estimate of Combining Ability and Heterosis for Yield and Yield Components in Tomato (Lycopersicon esculentum Mill.). J Biol Environ Sci. 2012; 6(17):129134.

Biswas MK, Mondal MAA, Hossain M, Islam R. Selection of suitable parents in the development of potato hybrids in Bangladesh. Chinese Potato J. 2005; 19:193-197.

CNPSH (Centro Nacional de producción de Semilla de Hortalizas). Presentación de Variedades. Villa Montenegro, Cochabamba. 2001; 24 pp.

Gabriel J, Magne J, Crespo M, Plata G, Angulo A, García R. Caracterización agronómica, morfológica y de resistencia a virus en 74 coleccio53 nes de trabajo del banco de germoplasma de tomate (Lycopersicum sculentum). Páginas 110 in Informe anual de Proyectos gestión 2007-2008, Fundación PROINPA, Cochabamba, Bolivia. 2008.

Ghezan G. Producción de tomate fresco. PROCISUR. 2000.

Govindarasu P, Muthukrishnan CR, Irulappan I. Combining-ability for yield and its components in tomato. Scientia Horticulturae. 1981; 14:125-130.

Griffing B. Concept of general and specific combining ability in relation to diallel crossing system. Aust J Biol Sci. 1956; 9:463-493.

Hannan MM, Ahmed MB, Roy UK, Razvy MA, Haydar A, Rahman MA, et al. Heterosis, Combining Ability and Genetics for Brix\%, Days to First Fruit Ripening and Yield in Tomato ( $L y$ copersicon esculentum Mill.). Middle-East Journal of Scientific Research. 2007; 2 (3-4): 128-131.

Hannan MM, Biswas MK, Ahmed MB, Hossain M, Islam R. Combining Ability Analysis of Yi eld and Yield Components in Tomato (Lycopersicum esculentum Mill.). Turk J Bot. 2007; 31:550-563.

IPGRI. Descriptores para el tomate (Lycopersicon spp.). Bogota, Colombia. 2008; 49 pp.

Khan MA, Cheema KL, Masood A, Sadaqat HA. Combining ability in cotton (Gossypium hirsutum L.). J Agric Res. 1991; 29:311-318.

Martinez-Garza A. Diseños experimentales: Métodos y elementos de teoría. Editorial Tri llas, México, DF. México. 1998; 756 pp.

Mirshamsi A, Farsi M, Shahriari F, Nemati H. Estimation of heterosis and combining ability for yield components and earliness in seven tomato lines using diallel crossing method. 
Agri cultural Sciences and Technology Journal. 2006; 20(3):1-12.

Mital RK, Singh HN. Genetic of fruit charac teristics in tomato, Indian J Agria Res. 1977; 11:104-114.

Ortiz R, Golmirzaie AM. Combining ability analysis and correlation between breeding values in true potato seed. Plant Breeding. 2004; 123:564-567.

Pratta G, Zorzoli R, Picardi LA. Diallel analysis of production trait among domestic, exotic and mutant germplasm of Lycopersicon. Genet Mol Res. 2003; 2:206-213.

Reque S. Informe de consultoría sobre el estudio de identificación de aéreas de producción y variedades cultivadas de tomate para semilla y consumo en Bolivia. Programa Nacional de Semilla (PNS), Cochabamba, Bolivia. 2010.
SAS Institute Inc. SAS/STAT Users Guide, Version 9.2, Fourth Edition, Vol. 2, SAS Institute Inc., Cary, N.C. 2004.

Sekhar L, Prakash BG, Salimath PM, Channayya P, Hiremath Sridevi O, Patil AA. Implication of heterosis and combinig ability among productive Single cross Hybrids in tomato. Elec. J. Plant Breeding. 2010; 1(4):706-711.

Sprague GF (eds). Plant Breeding. Ames, IA, USA: Iowa State University Press. 1966.

Yaqoob M, Hassan G, Mahmood G, Shah NH. Combining ability studies for some quality tra its in cotton (Gossypium hirsutum L.). J Pure Appl Sci. 1997; 16:47-50. 